\title{
Impact of Investment Activity on the Value of Agricultural Business
}

\author{
Samygin D.Yu.* \\ Penza State University \\ Penza, Russia \\ e-mail: vekont82@mail.ru
}

Ilyasova A.V.

\author{
Penza State Technological University \\ Penza, Russia \\ e-mail: strochno@mail.ru
}

\author{
Baryshnikov N.G. \\ Penza State Agrarian University \\ Penza, Russia \\ e-mail: stoik55@mail.ru
}

\author{
Karmyshova Yu.V. \\ Penza State Technological University \\ Penza, Russia \\ e-mail: k-arm@yandex.ru
}

\begin{abstract}
The problem of increasing investment activity of agricultural business is raised, which is difficult to solve only at the expense of mechanisms of budget and credit support. It was revealed that against the background of the growth of borrowed capital, private investments in agriculture are declining. In an uncertain environment, investment decision support tools are needed to describe the return on investment and its potential effectiveness. The methodology of investment attractiveness diagnostics is systematized by the indicators of the method of estimation of economic value added and supplemented by models of dependence of yield spread on invested capital. The study was carried out taking into account two scenarios of product price growth under conditions: openness of the domestic market (scenario 1) and antisequences (scenario 2). Analytical and model calculations show the existence of economic incentives from investment of financial resources in agricultural business under both scenarios. Owners of invested funds in the first scenario will receive a large value, in the second scenario - a large yield of agricultural business. The results of the study will be useful to the agribusiness management bodies to coordinate strategic decisions to create a favorable investment climate in agriculture.
\end{abstract}

Keywords - agrarian business, investment attractiveness, invested capital, economic added value, profitability spread.

\section{INTRODUCTION}

The main path of progressive development of the agrarian economy is the widespread introduction of innovations in agricultural production, as large foreign companies in biotechnology and genetic engineering have done. In order for agriculture to take an innovative path of development, it is necessary to change the traditional agricultural sector [3]. We need an investment breakthrough and an increase in the investment attractiveness of the agricultural sector.

The catalyst for warming the investment climate in the agricultural business of the Russian Federation was the adoption of the most important strategic documents on agriculture, which allowed increasing the budget support and investment attractiveness of agriculture [11]. Given the budgetary constraints, the authorities seek to use other sources of additional funding for farmers. Only at the expense of preferential lending mechanisms it is possible to attract more than 1 trillion rubles of bank capital to the agricultural sphere annually.

Regional experience of attracting investments in agricultural business shows that during the period of agricultural policy activation there is an increase in budgetary and borrowed sources of financial resources for agriculture.

For example, in the Penza region at increase in total amount of investments in 2019 in comparison with 2010 almost by 3.5 times, loan sources of financing of agricultural production grew for 2010-2019 more than by 4 times [9].

Earlier studies show that the growth of attracted funds of credit institutions in recent years was due only to the intensification of financially stable agricultural firms, whose credit potential for objective reasons is limited [4]

A large part of agricultural producers has low creditworthiness indicators, which automatically prevents them from attracting money resources of banks under this component [6].

According to our calculations, only in the last 3 years (2017-2019) in Penza region against the background of growth of long-term $(27 \%)$ and short-term (39\%) sources there was a decrease in equity and authorized capital $(-25 \%)$, which indicates low investment attractiveness of the agricultural sector for private investors [14].

The fact is that for commercial banks the decision to invest in agricultural business is made on the basis of indicators of creditworthiness, which have recently improved significantly due to the agricultural policy of increasing the financial stability of producers in the country. Given the objective risks of investment in agriculture and the loss of the desired profits for private investors, this is not enough.

In order to mobilize the involved sources of financing and find new reserves, the involvement of free capital of other investors requires fundamentally different instruments of organizational and economic mechanism to increase the investment attractiveness of agricultural business, which allow changing the view of capital owners on the return on invested funds. 
The research purpose is to create the instruments of support of investment decisions in the agrarian sector including, a method of the analysis of economic added value, a measuring instrument of financial risks and model of assessment of efficiency of potential investments in agrarian business.

\section{METHODOLOGY}

It is expedient to construct methodology of functional diagnostics of investment attractiveness of the agrarian sector by methods of quantitative valuation of business which can be subdivided into two groups:

1. Method of net assets and method of discounting of future income.

\section{Method of economic added value of agrarian business.}

The methods of the first group and results received on their basis, allow estimating the general prospects of its continuation in the context of future income of agricultural activity. The second method gives the chance to estimate possible gain of market value of business in the future. Therefore, use these methods in total is economically reasonable and expedient.

The first group of methods is standard, the applied indicators and an algorithm of calculations are stated in normative legal acts of the Ministry of Finance of the Russian Federation and Ministry of Economics of Russia. The second group - is based on discounting of cash flows by method of assessment of economic added value.

The methodology of the analysis of economic added value consists of several stages and includes a number of indicators (fig. 1).

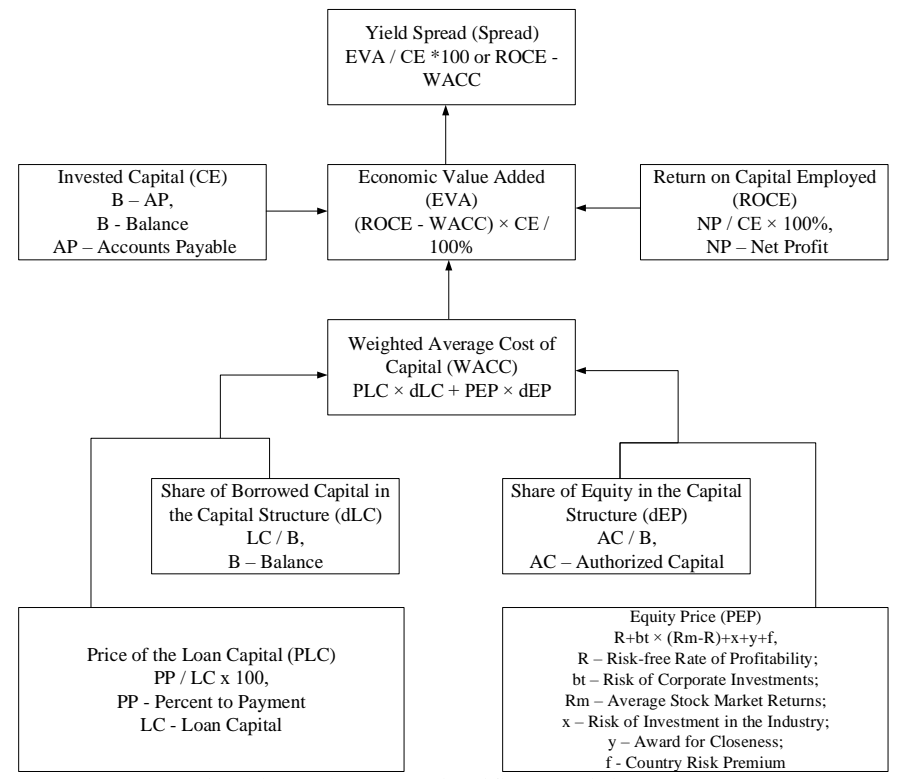

Source: systematized by authors on scientific materials $[2,5,7,13,17]$

Fig. 1. Method of diagnostics of economic added value

At the same time for the investor it is important to know as well as on how many the market value of the enterprise at an investment will change in it additional resources that is what gain of market value to expect from each monetary unit invested in business. In this case it is necessary to carry out functional diagnostics of establishment of nature of communication and parameters of interdependence between the called criteria. Therefore methods of financial management in a research are complemented with method of statistical groups and the econometric analysis of factors of economic added value on the basis of 220 agricultural producers of the Penza region given to financial statements during 2012-2019.

The determination of number of groups of landowners was determined by qualitative sign as which variation basis the criterion of yield on the invested capital was taken. Levels of yield on the invested capital which are expedient for comparing with loss ratio, the level of weighted average cost of capital, the average level of profitability on the region, the rate of inflation, level of alternative profitability are chosen as gradation of variation sign.

All calculations were carried out taking into account that action of the mode of "anti-sanctions" in the field of embargo of import of agrarian products from a number of foreign countries could affect the price of business. The guaranteed sales market during this period and increase in prices on the basis of change of a ratio of supply and demand for food due to decrease in the last could be one of factors of growth of cost of business.

In order to consider this fact discounting of future income it is carried out in two scenarios - the scenario of openness of the markets of food for import and insignificant increase in prices for agricultural products (2012-2014, scenario 1), the scenario of influence of "anti-sanctions" and increase in prices on this basis (2015-2019, scenario 2).

The calculation of financial performance was made with use of a specialized package of application programs of financial management «FinEkAnaliz» and «Your financial analyst». Functional diagnostics of parameters of interrelation of factors of economic added value is performed about use of a statistical package of SPSS.

\section{RESULTS AND DISCUSSION}

Diagnostics of cost of agrarian business which is carried out by the first group of methods allowed receiving the final quotation of cost calculated as an arithmetic average of estimates, by the specified methods (Figure 2).

The cost calculated by method of discounting of future income (more than 42 billion rubles), much more (by 1.8 times) surpasses the estimated size of net assets (about 24 billion rubles). The comparative analysis of the received results confirms a hypothesis of the leading scientists that it is at the moment more favorable to continue agrarian business, than to sell it.

At an evaluation stage of equity several intermediate iterations according to equity price factors are carried out: 


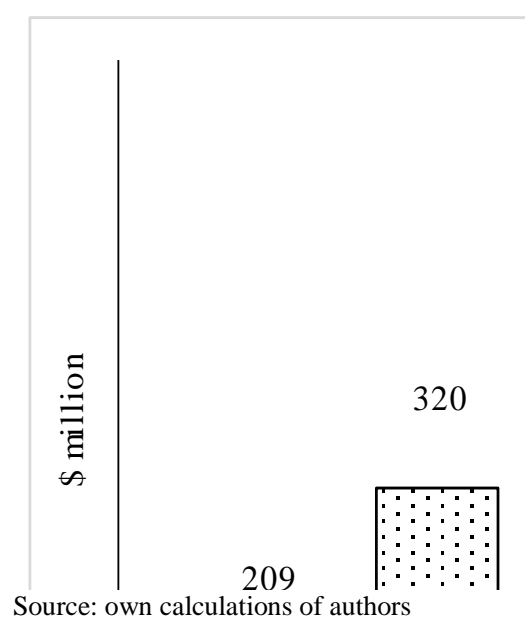

Fig. 2. Diagnostics of cost of agrarian business

1. The analysis of factors of the price of equity of agricultural enterprises of the Penza region (fig. 3).

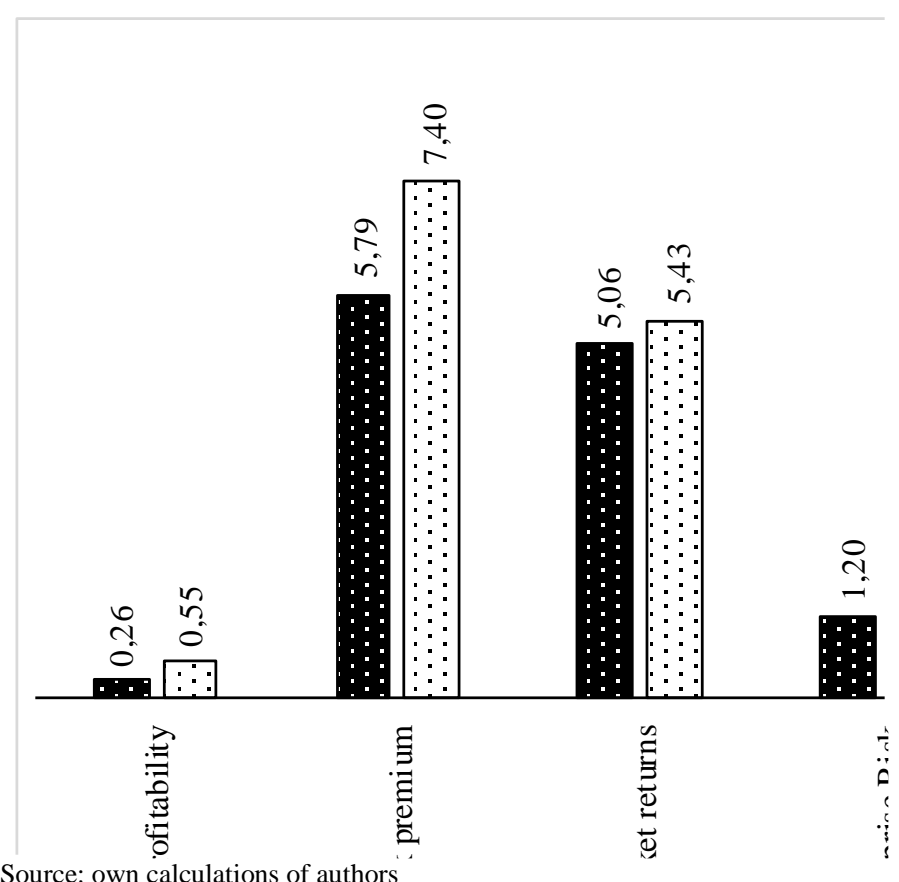

Fig. 3. Analysis of factors of the price of equity of agricultural enterprises of the Penza region

The level of a nominal risk-free rate appeared below the rate of inflation. As a result the risk of this investment can be estimated as average on the market. The award for closeness makes $75 \%$ of a risk-free rate. Thus, on the basis of the carried-out analysis it is possible to draw a conclusion that the risk of investment can be estimated at agricultural industry of the Penza region as high.

2. The analysis of parameters of economic added value (fig. 4).

The researches demonstrate gain of market value of agricultural firms over the book value of assets in recent years and a positive trend in this direction. Thus, owners lost the invested capital due to profitability loss, only in 2014, and before (scenario 1) on average for the period the earned profitability exceeded the size demanded by investors more than for $7 \%$. Gain of market value of agricultural enterprises over the book value of assets was more than 280 million rubles. The similar situation developed also during the subsequent period (scenario 2) where on average the earned profitability exceeded the size demanded by investors more than for $2 \%$, and gain of market value of assets over their book value was already more than 1 billion 306 million rubles. All this allows speaking about the existing incentive for an investment owners of additional resources in an entrepreneurial activity and business of this industry both on the first, and according to the second scenario.

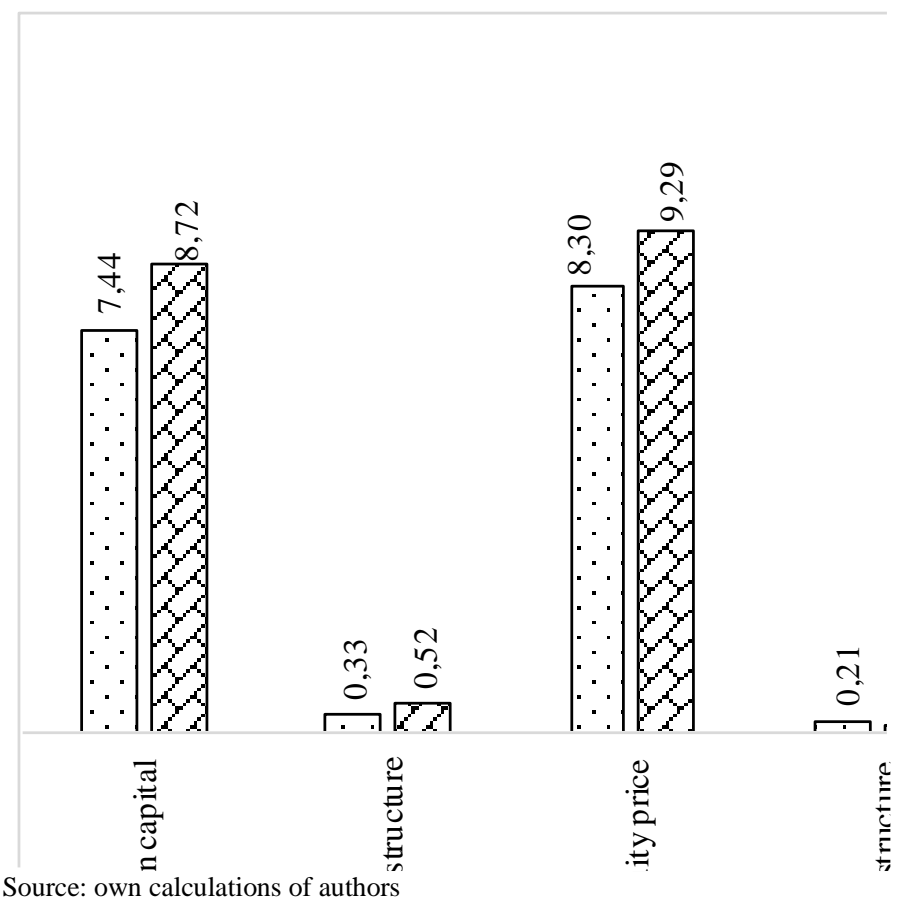

Fig. 4. Diagnostics of parameters of economic added value in agricultural business of the Penza region

The spread of profitability shows that each invested ruble leads to growth of market value of agrarian business according to the first scenario 1 more than for 7 kopeks, according to the second scenario 2 - almost for 2.5 kopeks. The parameters of such efficiency of investments allow reasoning the necessary amount of injections to the real sector of agrarian economy at the determined market value of business.

The method of statistical groups revealed communications between factors of the economic added value (tab. 1).

The method of statistical groups allowed confirming a hypothesis that in process of growth of level of yield on the invested capital the economic added value increases and the profitability spread raises. At the same time, in structure of the invested capital the greatest share (nearly $38.5 \%$ ) belongs to landowners with the level of yield on the invested capital more than a level of alternative profitability (15\%). 
TABLE I. GROUP OF THE AGRICULTURAL ORGANIZATIONS OF THE PENZA REGION IN SIZE OF YIELD ON THE INVESTED CAPITAL IN AGRARIAN BUSINESS

\begin{tabular}{|c|c|c|c|c|c|}
\hline 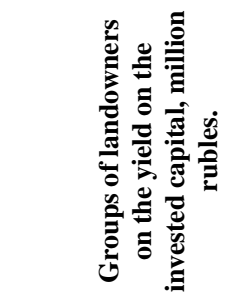 & 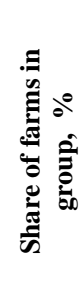 & 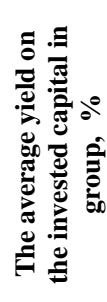 & 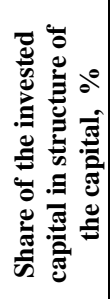 & 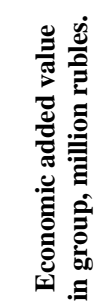 & 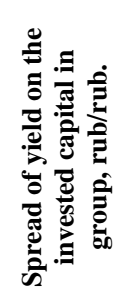 \\
\hline up to $0 \%$ & 21.50 & -15.53 & 75.65 & -1297 & -25.87 \\
\hline from 0 to $6.56 \%$ & 28.50 & 1.25 & 75.37 & -1137 & -9.05 \\
\hline from 6.56 to $8.88 \%$ & 4.21 & 6.89 & 66.72 & -37.1 & -3.46 \\
\hline from 8.88 to $11.4 \%$ & 4.67 & 10 & 83.73 & -0.16 & -0.07 \\
\hline from 11.4 to $15.0 \%$ & 7.48 & 13.19 & 88.56 & 83.84 & 3.11 \\
\hline over $15.0 \%$ & 33.64 & 31.56 & 86.99 & 2915.9 & 21.57 \\
\hline
\end{tabular}

Growth of yield on the invested capital with a bigger share of probability is connected with increase in a share of the invested capital in structure of all capital. So, landowners with the yield on the invested capital are higher than average on the region higher than $80 \%$ have a share of this capital. Besides, these producers have an opportunity to increase the market value at increase in the relative volumes of investment.

The functional dependence of a spread of profitability on volume of the invested capital (tab. 2) shows that the most strong connection is shown in the form of sedate model.

TABLE II. FUNCTIONAL DEPENDENCES OF A SPREAD OF PROFITABILITY (Y) ON THE INVESTED CAPITAL (X) IN AGRARIAN BUSINESS

\begin{tabular}{|c|c|c|c|c|}
\hline 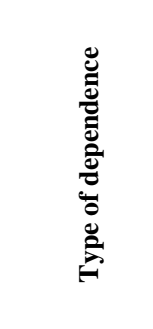 & 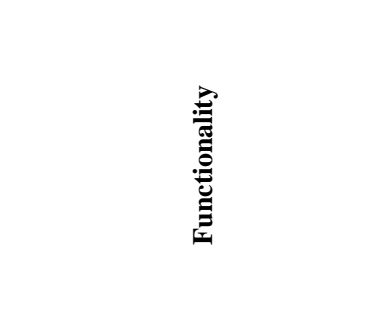 & 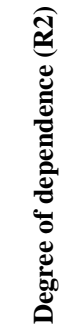 & 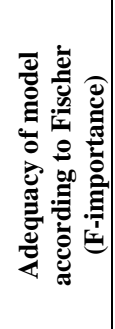 & 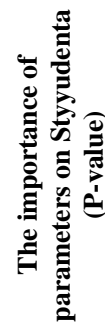 \\
\hline Linear & $y=419072-0.4184 x$ & 0.01 & 0.0478 & 0.0755 \\
\hline Logarithmic & $\mathrm{y}=4 \mathrm{E}+06-4 \mathrm{E}+05 \ln (\mathrm{x})$ & 0.18 & 0.0569 & 0.1214 \\
\hline Polynomial & $y=8 E-07 x^{2}-1.695 x+501071$ & 0.01 & 0.7456 & 0.4553 \\
\hline Sedate & $\mathrm{y}=330,217,711.45 \mathrm{x}^{1.04}$ & 0.98 & 0.0034 & 0.0001 \\
\hline
\end{tabular}

With the probability of $98 \%$ each invested ruble will promote growth of market value, and the elasticity of model demonstrates that at increase in the invested capital by $1 \%$, market value will grow by $1.04 \%$.

Check of adequacy of sedate model and the importance of its parameters shows that it meets Fischer's condition (the F-importance $=0.0034<0.05)$ and to Styyudent's criteria $(\mathrm{P}$-value $=0.0001<0.05)$, that is can be used for creation of expected values of a spread of yield on the invested capital from the size of investments.

\section{CONCLUSION}

Generalizing results of the conducted research, it is possible to conclude that progress on attraction in agrarian business of investment resources is connected only with the banking sector. At the same time, the taken steps did not allow expressing interest to capital of other investors who are frightened off by high agrarian risks, instability of a situation in the food market and other calls. The strategic instruments of diagnostics of investment attractiveness used for today do not allow proving efficiency of future investments to the agrarian sector.

At the same time calculations showed that return from invested funds in agrarian business takes place, the earned profitability exceeds the size demanded by investors. The general conclusions are that the risk of conducting agricultural activity is higher where the rate of increase in value of agrarian business for each ruble of additional investments is higher, in other case the gain of market value of assets over their book value is higher. In other words, owners of the invested means in the conditions of the mode of "antisanctions" will receive big profitability of the business, and in the conditions of openness of the markets - its big cost.

In modern Russian conditions of development of agricultural industry it is difficult to do without obvious description of investment processes and their influence on operational performance of the industry. The calculations which are carried out by us with use of instruments of functional diagnostics of the investment capital allow showing return from the invested capital.

\section{References}

[1] N. Altaf, "Economic value added or earnings: What explains marke value in Indian firms?", Future Busin. J., vol. 2, no. 2, pp. 152-166, 2016.

2] M. Alipour, M.E Pejman, "The impact of performance measures, leverage and efficiency on market value added: Evidence from Iran", Global Econ. and Manag. Rev., vol. 20, no. 1, pp. 6-14, 2015.

[3] G.V. Bespahotnyj, "About development of the new concept of the state support of agricultural enterprises", Econ. of agricult. and proc. enterprises, no. 6, pp. 8-11, 2019.

[4] J.J. Cordeiro, D. Donald, J.R Kent, "Do EVA adopters outperform their industry peers? Evidence from security analyst earnings forecasts", Amer. Busin. Rev., vol. 19, no. 2, p. 57, 2001.

[5] M.E. Cucagna, P.D. Goldsmith, "Value adding in the agri-food value chain”, Int. Food and Agribusin. Manag. Rev., vol. 21, no. 3, pp. 293-316, 2018.

[6] V. Daskovskiy, V. Kiselev, "New concept, approaches and methods of business assessment", Economist, no 8, pp. 25-32, 2019.

[7] A. Jahangir, W. Darron, W. Gizelle, "The value of financial advice: An analysis of the investment performance of advised and non-advised individual investors", Investment Anal. J., vol. 45, pp. 63-74.

[8] I.A. Maslova, A.A. Gudkov, "Analytical procedures for estimation of added value of branches of national economy", Manag. Account., no. 6, pp. 37-49, 2017.

[9] D.Yu. Samygin, N.G. Baryshnikov, L.A. Mizjurkina, "Models of Scenario Forecasting of the Region's Agriculture", Econ. of reg., vol. 15 , no. 3 , pp. 865-879, 2019.

[10] G. Chibrikov, "Digital Revolution in Financial Technology", Economist, no. 4, pp. 70-79, 2018. 
[11] N. Baryshnikov, D. Samygin, D. Murzin, "Forecasting bankruptcy models for agrarian business", IOP Conf. Ser. Earth and Environmental Sci., no. 274, 2019.

[12] V. Korotchenya, "Digital agriculture and agricultural production efficiency: exploring prospects for Russia”, Revista ESPACIOS, vol. 40, no. 22, pp. 22-36, 2019.

[13] L.A. Russell, Cost Efficiency and Capital Structure in Farms and Cooperatives (Unpublished Dissertation). Kansas State Univer., 2013.

[14] D.Y. Samygin, A.A. Kudryavtsev, "Strategic instruments of state support distribution in the agrarian sector", Ekon. Politika, vol. 13, no. 5, pp. 156-175, 2018.
[15] F.G. Santeramo, D. Carlucci, B. De Devitiis, A. Secci, A. Stasi, R. Viscecchiaa, G. Nardone, "Emerging trends in European food, diets and food industry", Food Res. Int., no. 104, pp. 39-47, 2018.

[16] M. Sillano, J. de Dios Ortúzar, "Willingness-to-pay estimation with mixed logit models: some new evidence", Environment and Plann. A, no. 37, pp. 525-50, 2005.

[17] C.G. Turvey, L. Lake, E. van Duren, D. Sparling, "The relationship between economic value added and the stock market performance of agribusiness firms", Agribusin., no. 16, pp. 399-416, 2000. 